\title{
Sediment Thickness Estimation in Serpong Experimental Power Reactor Site Using HVSR Method
}

\author{
Theo A Ryanto*1, Eko R Iswanto', Yuni Indrawati ${ }^{1}$, Abimanyu BW Setiaji ${ }^{1}$, Hadi Suntoko ${ }^{1}$ \\ ${ }^{1}$ Center for Nuclear Energy System, National Nuclear Energy Agency (BATAN) \\ JI. Kuningan Barat, Mampang Prapatan, South Jakarta, DKI Jakarta, Indonesia
}

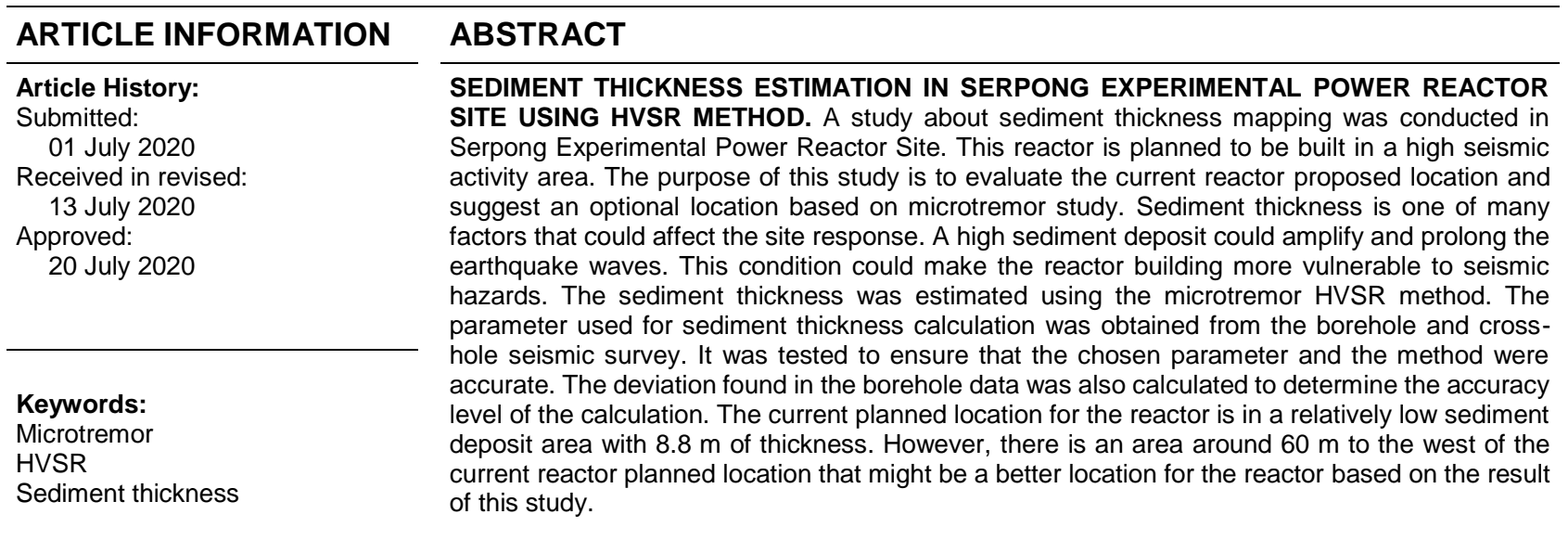

\begin{abstract}
ABSTRAK
ESTIMASI KETEBALAN SEDIMEN DI TAPAK REAKTOR DAYA EKSPERIMENTAL DENGAN METODE HVSR. Studi tentang pemetaan ketebalan sedimen telah dilakukan di tapak Reaktor Daya Eksperimental Serpong. Reaktor ini direncanakan untuk dibangun di daerah dengan aktivitas seismik yang tinggi. Tujuan dari penelitian ini adalah untuk mengevaluasi posisi lokasi reaktor yang direncanakan saat ini, dan memberi masukan lokasi opsional berdasar studi mikrotremor. Ketebalan sedimen adalah satu dari beberapa faktor yang dapat mempengaruhi site response dari suatu daerah. Keberadaan endapan sedimen yang tebal dapat mengamplifikasi dan memperpanjang gelombang gempa. Kondisi ini dapat membuat bangunan reaktor menjadi lebih rentan terhadap bahaya gempa. Pada studi ini, ketebalan sedimen di estimasikan dengan metode mikrotremor HVSR. Parameter yang digunakan untuk perhitungan didapatkan dari data bor dan survei seismik cross-hole lalu diuji untuk memastikan bahwa parameter dan metode yang digunakan akurat. Simpangan hasil perhitungan terhadap data bor digunakan untuk menentukan tingkat keakuratan dari hasil perhitungan. Lokasi tapak yang direncanakan sudah memiliki estimasi endapan sedimen yang relatif rendah, yaitu setebal $8,8 \mathrm{~m}$. Akan tetapi, area sekitar 60 $\mathrm{m}$ di sebelah barat dari lokasi reaktor direkomendasikan sebagai area yang lebih baik berdasarkan analisis yang telah dilakukan pada penelitian ini. Kata kunci: mikrotremor, HVSR, ketebalan sedimen
\end{abstract}

(c) 2020 Jurnal Pengembangan Energi Nuklir. All rights reserved

\section{INTRODUCTION}

The National Nuclear Energy Agency (BATAN) was planning to develop an Experimental Power Reactor or Reaktor Daya Eksperimental (RDE) as a program to support the National Medium Term Development Plan (RPJMN) 2015 - 2019[1]. The reactor is planned to be constructed in the PUSPIPTEK area, South Tangerang district, northwest part of Java Island. The area is located near the subduction zone area, and the seismic activity is quite high due to the tectonic condition[2]. Seismic safety is one

${ }^{*}$ Correspondence author.

E-mail: theo.alvin@batan.go.id of many safety aspects to be considered in reactor construction planning. Therefore, all research that could support the earthquake hazard assessment should be conducted to ensure building safety. The international safety guide on seismic hazard evaluation for nuclear installation was established by International Atomic Energy Agency (IAEA) in IAEA Safety Standard Series No. SSG-9[3]. In Indonesia, the safety standard was established by the Nuclear Energy Regulatory Agency (BAPETEN) in BAPETEN Chairman Regulation No. 8 in 2013 
about Nuclear Installation Site Evaluation in Seismicity Aspect[4].

When an earthquake happens, seismic waves would be radiated from the source of the earthquake towards the surface. The seismic waves characteristics recorded on the surface could differ from one area to another, even though they are from the same earthquake source. The topography and geologic condition in the near-surface area could alter the behavior of the seismic wave. The shaking caused by the earthquake could be amplified or even prolonged because of the surface condition. This effect is widely known as the site response[5]. The sediment deposit of the area could also affect the site response. Thick and soft sediment would amplify the seismic waves. The area that has more soft-sediment deposits is more vulnerable to earthquakes [6]. This condition also needs to be considered in the reactor safety analysis. The SSG -9 states that the presence of a sedimentary basin determines the ground motion duration. Therefore, if the reactor is planned to be built in the area with high sediment deposit, the engineering planning to anticipate the seismic hazard potential could be costly and should be avoided if possible.

Borehole drilling and coring are the commonly used method for sediment thickness determination. This method would give the most reliable result to determine sediment thickness, but also requires a lot of time and resources. There are alternatives to estimate the sediment thickness; one of them is microtremor horizontal to vertical spectral ratio (HVSR) methods[7][10].

Microtremor (HVSR) is a geophysical method that measures site fundamental resonance frequency or predominant frequency $\left(f_{0}\right)$ value of the investigated sites. Many factors may influence the frequency of an earthquake wave, which includes: the dynamic characteristics at the focal region when the accumulated energy was released, the wave motion radiation characteristics when the waves travel to the investigated sites, and the dynamics characteristics at the surface layer of the investigated sites or the site effects. The site effects are assumed strong enough to surpass every other factor[11], [12]. Because of that, the measured predominant frequency is considered to be the resonance frequency of the sediments overlying the bedrock. This method was firstly introduced by Nakamura (1989)[12] and widely used to determine the site response.

HVSR method uses a three-component measurement of ambient seismic noise, consisting of long-period microtremor (induced by natural sources namely wind, ocean waves, etc. with periods above 2s) and short-period microtremor (caused by human artificial noise such as traffic, machinery, etc. with periods below 2s)[13]. Therefore, no artificial source such as explosives or hammer blow is needed for data acquisition. The three-component measurement needs microtremor acquisition devices with three sensors; two horizontal sensors (north-south and east-west) and a vertical sensor. The ambient seismic noise would be recorded in three-component simultaneously.

The resonant frequency value from microtremor HVSR measurement could be used to estimate the thickness of the sediment layer[14], [15]. Compared to borehole drilling, this method is more efficient in estimating sediment layer thickness. There would be a difference from the estimated value of sediment thickness to the thickness value from the borehole. As an alternative, this estimation could be used as a borehole location recommendation before executing the borehole drilling.

The purpose of this study is to evaluate the seismic hazard safety of the current planned reactor location and suggest an optional location that has better safety conditions based on the sediment thickness. The sediment thickness would be estimated using the microtremor HVSR method and evaluated with the borehole data.

\section{METHODS}

The methodology of this study consists of three stages, as shown in figure 1. The first stage is the microtremor data processing to obtain the resonant frequency of the soft sediment deposit. The next step is the parameter analysis that concludes shear wave velocity $\left(V_{s}\right)$ analysis to estimate the averaged $v_{s}$ of sediment deposit and depth dependence of velocity. The last stage is the calculation of the estimated sediment thickness. 


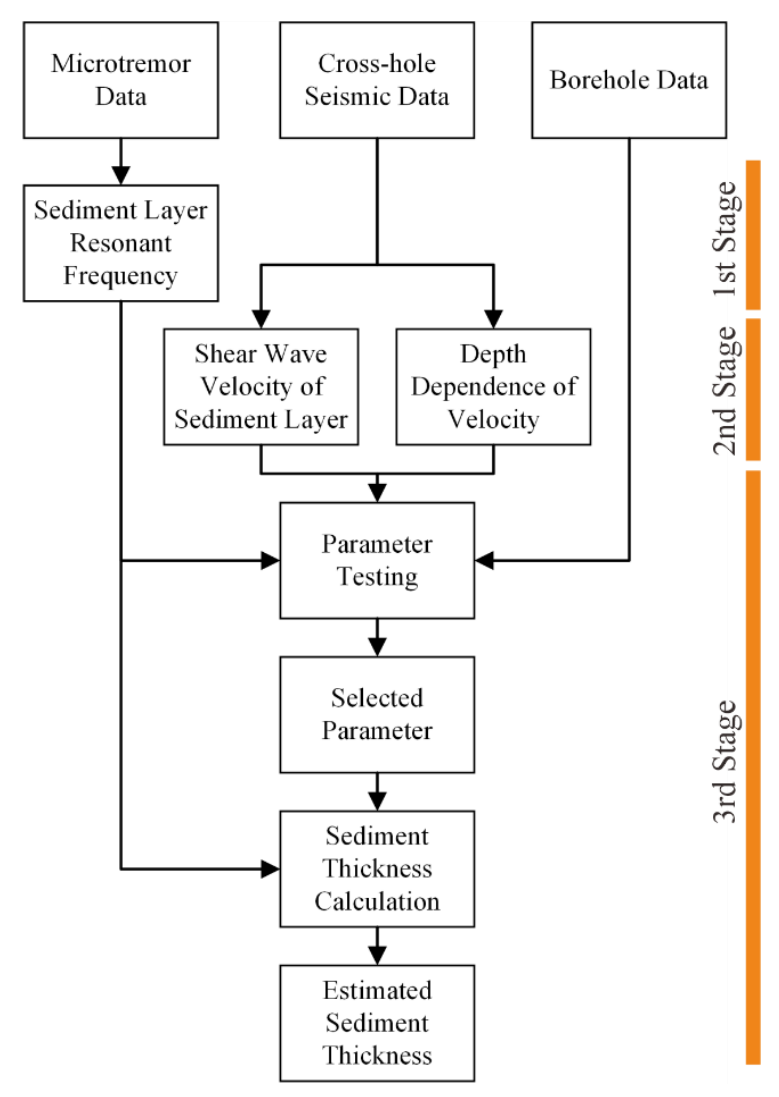

Figure 1. Study Workflow.

\subsection{Microtremor HVSR Data Processing}

This study uses microtremor HVSR data on the RDE site area that has been previously published by Iswanto (2019)[16]. There are 15 measurement points scattered around the RDE site area with $100-300 \mathrm{~m}$ space in between, as shown in Figure 2. The microtremor data was reprocessed using Geopsy software. This software is an open-source toolset for ambient seismic data processing that has been used widely for microtremor HVSR analysis[17], [18].

The measurement points that contain multiple resonant frequencies would be analyzed further to obtain the resonant frequency of the soft sediment deposit. Therefore, microtremor data needs to be reprocessed. The sediment resonant frequency was used instead of predominant frequency because this study is focused on the soft sediment layer.

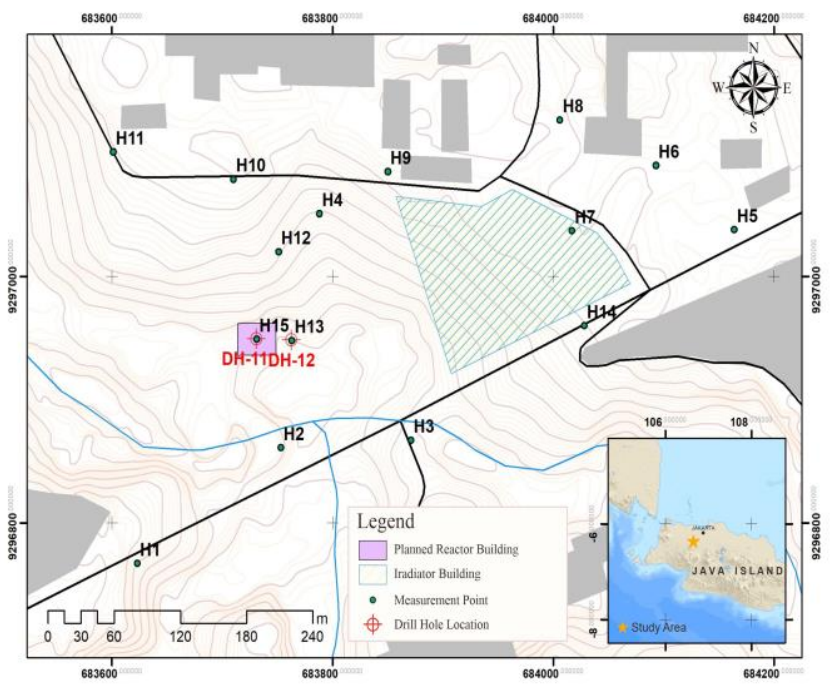

Figure 2. Measurement Points Location.

\subsection{Shear Wave Velocity $\left(v_{s}\right)$ Data}

The $v_{S}$ data used for this study is from the cross-hole seismic survey that has been conducted by BATAN[19]. This survey was executed in $\mathrm{DH}-12$. Based on the $v_{s}$ profile data from this survey, the sediment layer $V_{s}$ value from the area could be estimated, and the depth dependence of velocity $(x)$ could be calculated.

The $V_{S}$ profile would be analyzed to distinguish the soft sediment and bedrock layer based on $V_{S}$ contrast value. Averaged $V_{S}$ value of sediment layer and depth dependence of velocity could be calculated by generating the velocitydepth function from the $v_{s}$ profile[14].

\subsection{Sediment Thickness Estimation}

The fundamental assumption that is being used for sediment thickness estimation is the well-known quarter-wavelength approximation. This method assumes that the shear wave velocity up to a certain depth corresponds to a quarter wavelength at the resonant frequency of interest[20], [21]. Depend on this relation, and the resonant frequency may be calculated as:

$$
f_{r}=\frac{v_{s}}{4 h}
$$

Where $f_{r}$ is the resonance frequency of the sediment layer, $v_{S}$ is the shear wave velocity of the sediment layer, and $h$ is the thickness of the sediment layer. Figure 3 represents the basic principle of this relation. 


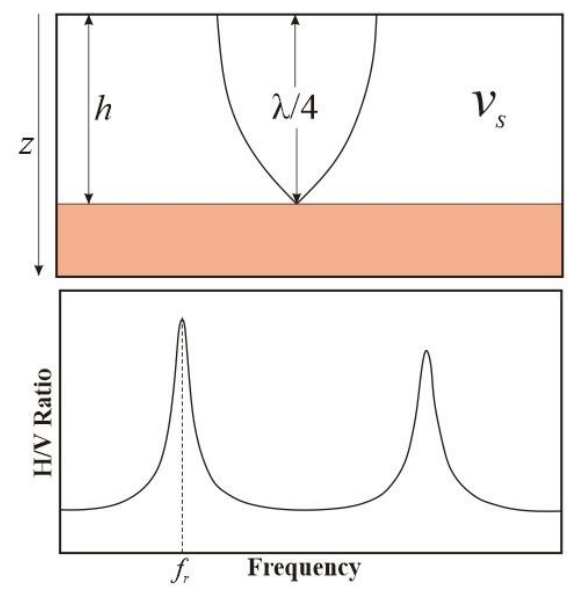

Figure 3. The Relation Between $f_{r}, v_{s}$ and $h$ [14].

The velocity-depth function of the sedimentary layer could be written as[14]:

$$
v_{s}(z)=v_{0}(1+Z)^{x}
$$

Where $v_{0}$ is the shear wave velocity in the surface, $Z=z / z_{0}$ with $z_{0}=1 \mathrm{~m}$, and $x$ represents the depth dependence of velocity. As $f_{r}$ is calculated as $\frac{1}{4} \mathrm{~T}_{0}$ (the wave travel time from the sediment layer to the surface), the dependency between depth and resonant frequency might be expressed in this form[14]:

$$
\begin{aligned}
T_{0}=\int_{0}^{h} \frac{d z}{v_{s}(z)} & =\frac{1}{v_{0}} \int_{0}^{h}(1+z)^{-x} d z \\
& =\frac{1}{v_{0}} \frac{(1+h)^{1-x}-1}{(1-x)}
\end{aligned}
$$

therefore,

$$
\begin{aligned}
f_{r}=\frac{1}{4 T_{0}} & =\frac{v_{0}(1-x)}{4\left[(1+h)^{1-x}--\right]} \\
h & =\left[\frac{v_{0}(1+x)}{4 f_{r}}+1\right]^{\frac{1}{1-x}}-1
\end{aligned}
$$

In this study, to ensure the parameters obtained are reliable, the sediment thickness from the measurement points that are in the same location with the borehole would be calculated for testing. The results would be compared with borehole data. Two methods of sediment thickness calculation could be used; by using averaged $v_{S}$ value of the sediment layer (1) or using depth-resonant frequency function (3). Both of the methods would also be tested to choose the best method and parameter that could deliver the minimum deviation result with borehole data.

\section{RESULTS AND DISCUSSION}

\subsection{Sediment Layer Resonant Frequency}

Generally, the predominant frequency is also assumed to be the resonant frequency of the soft sediments layer. That only applies if there are only two layers that exist, with only one layer of sediment, and the other one is the bedrock layer. If the geology condition is complicated with many layers of sediment above the bedrock, there might be multiple $\mathrm{H} / \mathrm{V}$ peaks caused by the existence of several sediment resonant frequencies[22]. The soft sediment resonant frequency would not always be the dominant frequency with the highest horizontal to vertical ratio (H/V) value. Therefore, the resonant frequency should not be selected based on the $\mathrm{H} / \mathrm{V}$ value only.

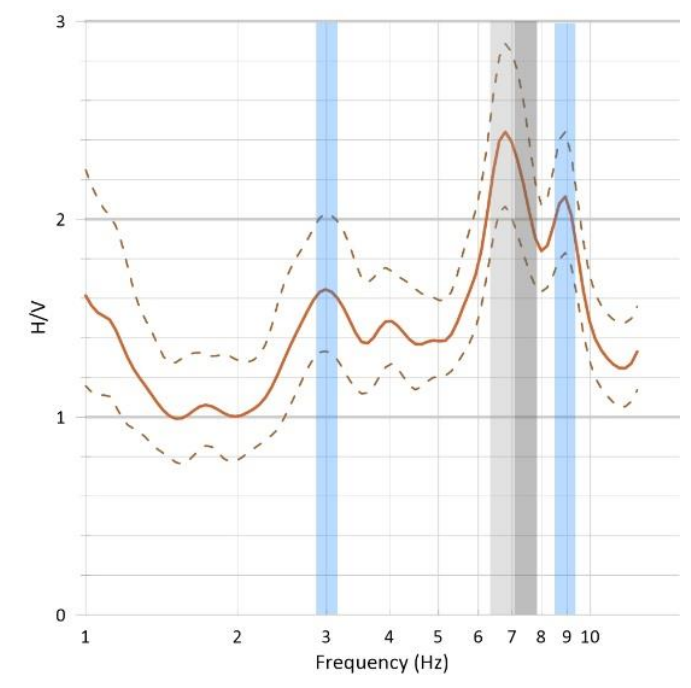

Figure 4. H/V Processing in H13.

The sediment deposit layer is assumed to be softer than the underneath layer in most conditions. Thus, the resonant frequency should be lower if compared to the others [8]. Figure 4 shows the $\mathrm{H} / \mathrm{V}$ data processing result in $\mathrm{H} 13$. There are $3 \mathrm{H} / \mathrm{V}$ peaks in this measurement point. The predominant frequency is shown with a grey bar with a frequency value of $7.11 \mathrm{~Hz}$ and has a $2.39 \mathrm{H} / \mathrm{V}$ ratio value. The other resonant frequencies are shown with blue bars. The first other peaks have a frequency of $3.07 \mathrm{~Hz}$ with a $1.64 \mathrm{H} / \mathrm{V}$ ratio value, and the other has a frequency of $8.92 \mathrm{~Hz}$ with an $\mathrm{H} / \mathrm{V}$ ratio value of 
2.11. In this case, the selected soft sediment layer resonant frequency value is the lowest one, which is $3.07 \mathrm{~Hz}$.

This peak selection method was applied in every measurement point that has multiple $\mathrm{H} / \mathrm{V}$ peaks to acquire the soft sediment resonant frequency of each point. The obtained sediment $\mathrm{f}_{\mathrm{r}}$ values vary from 3.07 to $5.37 \mathrm{~Hz}$, as shown in Table 1 . The predominant frequency $\left(\mathrm{f}_{0}\right)$ from the previous study by Iswanto (2019)[16] also included in this table.

\begin{tabular}{ccc}
$\begin{array}{c}\text { Table 1. Reprocessed Resonant Frequency Result } \\
\text { Measurement } \\
\text { Points }\end{array}$ & $\mathrm{f}_{\mathrm{r}}(\mathrm{Hz})$ & $\mathrm{f}_{0}(\mathrm{~Hz})$ \\
\hline H1 & 4.07 & 15.87 \\
H2 & 4.00 & 23.27 \\
H3 & 3.67 & 3.67 \\
H4 & 3.73 & 22.72 \\
H5 & 3.32 & 3.32 \\
H6 & 3.69 & 3.69 \\
H7 & 3.06 & 3.06 \\
H8 & 5.42 & 5.42 \\
H9 & 3.16 & 22.21 \\
H10 & 3.70 & 3.70 \\
H11 & 4.53 & 4.53 \\
H12 & 3.85 & 20.85 \\
H13 & 3.07 & 7.11 \\
H14 & 5.10 & 5.10 \\
H15 & 4.35 & 8.76 \\
\hline
\end{tabular}

\subsection{Sediment Layer $v_{s}$ Analysis}

The cross-hole seismic survey measures the shear wave velocity $\left(v_{s}\right)$ value from the surface to $50 \mathrm{~m}$ of depth. The averaged $v_{s}$ value for the entire $V_{s}$ profile $\left(V_{s b}\right)$ is $328.75 \mathrm{~m} / \mathrm{s}$. The $V_{S}$ value of the sediment layer is needed to calculate the sediment thickness in equation (1). Therefore, the boundary depth between the sediment deposit and the bedrock should be determined.

Generally, the shear wave would have a lower velocity when traveling through the soft sediment layer compared to hard bedrock. As shown in Figure 4., two layers could be differentiated based on the contrast in $V_{s}$ value. The top layer, from the surface to $19 \mathrm{~m}$ depth with averaged $V_{s}$ value $\left(v_{s a}\right)$ of $162.27 \mathrm{~m} / \mathrm{s}$, is considered to be the sediment layer.

The depth dependence of velocity $(x)$ constant is specific depends on geologic condition. This parameter could be determined by a downhole seismic survey[23]. The velocity-depth function of the sedimentary layer (2) was used to calculate $x$ constant value. The depth dependence of velocity value for the entire $V_{s}$ profile is 0.330, and for the estimated sediment layer, the $x$ value is 0.091 . The $x$ constant value difference between the entire layer and the estimated sediment layer is quite significant. This difference indicates that the $V_{s}$ gap between them is contrast and could be firmly differentiated. The function curve of $x$ value could be seen in Figure 5.

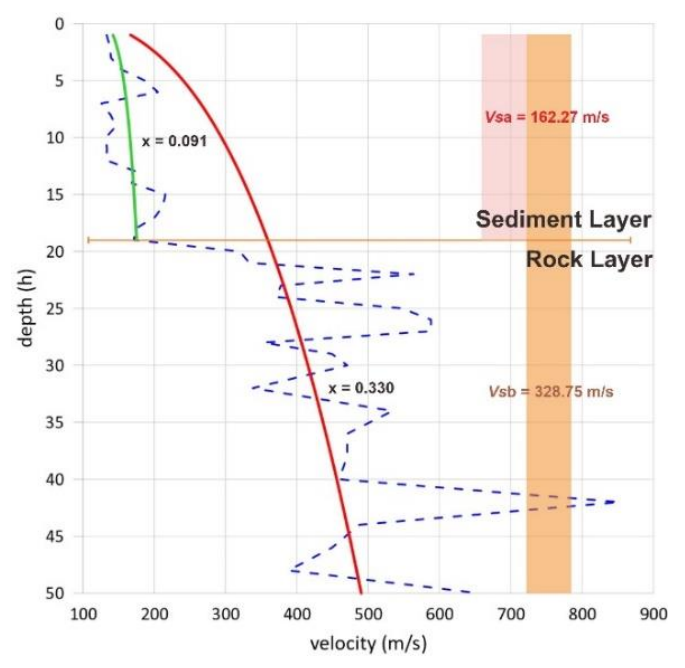

Figure 5. $V_{S}$ Profile Analysis.

\subsection{Thickness Estimation and Analysis}

The parameters obtained in the previous section value need to be tested to select which method has the minimum error and also to understand the relationship between the calculated $h$ value and the borehole data. The averaged $v_{s}$ values were calculated with equation (1), and the depth dependence of velocity values used equation (3). Both of them were calculated using the obtained sediment resonant frequency parameter. As shown in figure 2, H13 and H15 were measured in $\mathrm{DH}-12$ and $\mathrm{DH}-11$ borehole locations. Therefore, these measurement points were chosen for parameter testing.

The geological conditions in this area consist of multiple sedimentary layer formation that may have similar physical properties[16]. Geologically different types of sediment will not always have a different level of hardness. Therefore, the standard penetration test (nSPT) value in the borehole was also used to measure the sediment's hardness level. As for the standard, the site classification that classifies soil properties based on measured $v_{s 30}$ and nSPT value (Table 2) published by BSSC (2003)[24] 
was used. For more detailed analysis, sediment compactness classification based on the nSPT value was also used as a standard to define the compactness level of the soil. Table 3 shows the relation between the sediment compactness, relative density, and nSPT test value published by Teng (1962)[25]. The sediment thickness was calculated using equation (1) and (3) then plotted to the drill hole data to see the correlation between the depth and the nSPT value.

Table 2. Soil Classification

\begin{tabular}{cccc}
\multicolumn{4}{c}{ Table 2. Soil Classification } \\
\hline Site & $\boldsymbol{V}_{\boldsymbol{S} 30}(\mathrm{~m} / \mathrm{s})$ & nSPT & $\begin{array}{c}\text { General } \\
\text { Description }\end{array}$ \\
\hline Class & $>1500$ & N.A & Hard rock \\
A & $760-1500$ & N.A & Rock \\
B & $360-750$ & $>50$ & Very dense soil \\
C & $180-360$ & $15-50$ & Stiff soil \\
D & $<180$ & $<15$ & Soil \\
E & $<180$
\end{tabular}

Table 3. The Relation Between Sediment Compactness and nSPT Value

\begin{tabular}{ccc}
\hline Compactness & Relative Density & nSPT \\
\hline Very loose & $0 \%-15 \%$ & $0-4$ \\
Loose & $15 \%-35 \%$ & $4-10$ \\
Medium & $35 \%-60 \%$ & $10-30$ \\
Dense & $60 \%-85 \%$ & $30-50$ \\
Very Dense & $85 \%-100 \%$ & $>50$ \\
\hline
\end{tabular}

\section{DH-12}

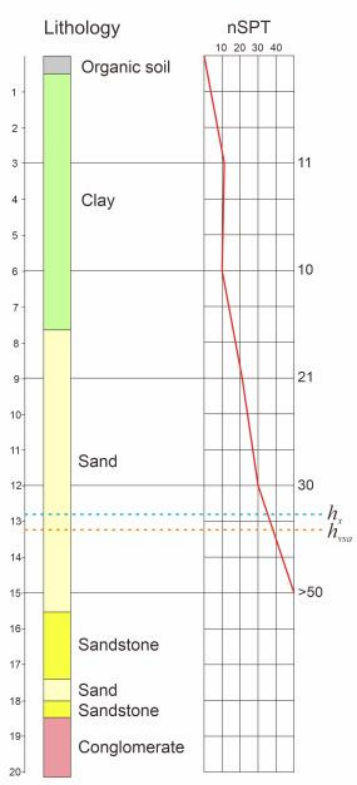

DH-11

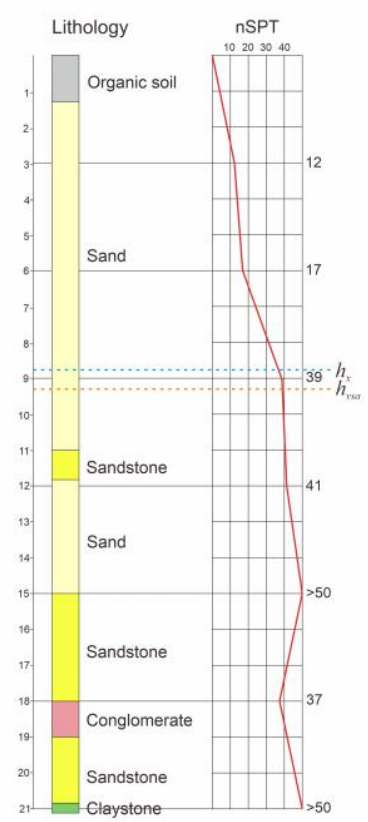

Figure 6. The Borehole and nSPT Data of DH-12 and DH11 with the Calculation Result of $h_{X}$ (Dashed Blue Line) and $h_{\text {VSa }}$ (Dashed Orange Line) Plotted.

The result shows that the sediment layer thickness calculated using $x$ constant value $\left(h_{x}\right)$ at DH-12 is $12.81 \mathrm{~m}$, and the calculation by using the sediment layer averaged $V_{s}$ value $\left(h_{V S a}\right)$ is $13.21 \mathrm{~m}$. At $\mathrm{DH}-11$ borehole, the calculation gives $h_{X}$ value of 8.81 , and $h_{V s a}$ is $9.33 \mathrm{~m}$. The correlation with borehole data results is shown in Figure 6.

Based on lithology information, all of the results correlate with the loose sand sediment layer. The results did not meet with any lithologic border; all of them were in the middle of the layer. This matter might be caused by the loose sand layer consist of varied materials size and compactness. As for the nSPT value, the results correlate with nSPT value between 30 40 , and the closest relation with the standard used is nSPT 30 that differentiates between dense and medium sediment. Therefore, the result is assumed to correlate with nSPT 30. Table 4 shows the deviation between the calculation result and nSPT 30 depth.

Table 4. Parameter Testing Calculation Result and The Deviation with nSPT 30 Depth

\begin{tabular}{|c|c|c|c|c|c|}
\hline \multirow{2}{*}{$\begin{array}{c}\text { Meas. } \\
\text { point }\end{array}$} & \multicolumn{2}{|c|}{$\mathrm{h}(\mathrm{m})$} & \multirow{2}{*}{$\begin{array}{l}\text { nSPT } 30 \\
\text { (m) }\end{array}$} & \multicolumn{2}{|c|}{ Deviation (m) } \\
\hline & $V_{s a}$ & $x$ & & $V_{s a}$ & $X$ \\
\hline H13 & 13.21 & 12.81 & 12 & 1.21 & 0.81 \\
\hline H15 & 9.33 & 8.81 & 8 & 1.33 & 0.81 \\
\hline \multicolumn{6}{|c|}{ Avg Deviation } \\
\hline & & $V_{s a}$ & $x$ & & \\
\hline & & 1.27 & 0.81 & & \\
\hline
\end{tabular}

The result shows $h_{X}$ has less deviation than $h_{\text {VSa. }}$. Therefore, the calculation method using the depth dependence of velocity is chosen. The average deviation of the thickness calculation is $0.81 \mathrm{~m}$. Based on the correlation result, the sediment layer is considered as a soft and stiff soil that has a very loose to medium compactness level. The calculation method was applied to all measurement points and gave sediment thickness results that vary from 7.0 to $12.9 \mathrm{~m}$, as shown in Table 5 . The measurement point that has the thickest sediment deposit is $\mathrm{H} 7$, and the thinnest is H8. 


\begin{tabular}{cc}
\hline $\begin{array}{c}\text { Measurement } \\
\text { Points }\end{array}$ & $\mathrm{h}(\mathrm{m})$ \\
\hline H1 & 9.5 \\
H2 & 9.6 \\
H3 & 10.6 \\
H4 & 10.4 \\
H5 & 11.8 \\
H6 & 10.5 \\
H7 & 12.9 \\
H8 & 7.0 \\
H9 & 12.4 \\
H10 & 10.5 \\
H11 & 8.4 \\
H12 & 10.0 \\
H13 & 12.8 \\
H14 & 7.4 \\
H15 & 8.8 \\
\hline
\end{tabular}

The sediment thickness result was processed into a contour map to give a better presentation of the data. As shown in Figure 7, the center of the study area tends to have a thick sediment deposit with 11.2 to $12.9 \mathrm{~m}$ of thickness. The H5, H7, H9, and H13 measurement points were in this area. This area is crossed by the small alluvial intermittent river channels that connected with the nearby river and made the surrounding swampy. This condition could cause more sediment to be deposited. The borehole data also show that $\mathrm{DH}-$ 12 has a thick clay deposit and none in $\mathrm{DH}-11$; this also confirms the possibility. The swampy area is a relatively ideal place for muddy sediment like clay to be deposited[26].

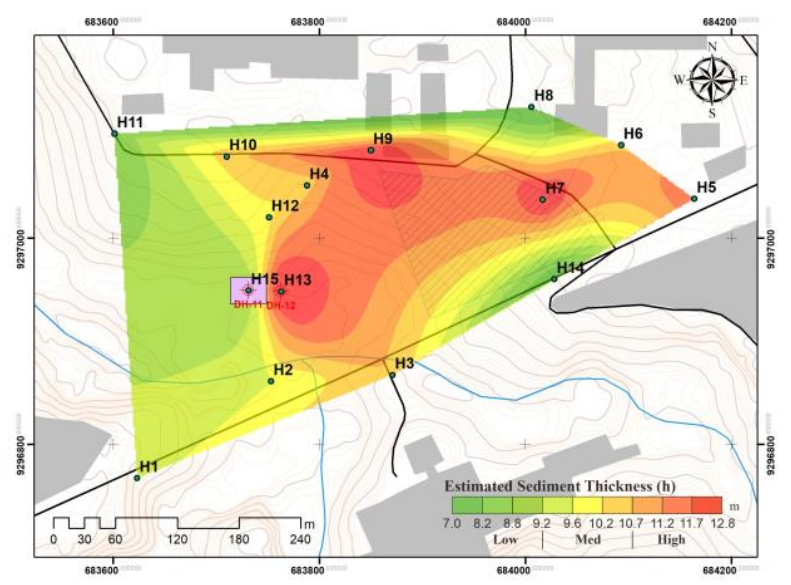

Figure 7. The Estimated Sediment Thickness Map.

The western part of the study area tends to have a relatively low sediment deposit. The sediment thickness ranged from $7.0-9.2 \mathrm{~m}$. As stated before, $\mathrm{DH}-11$ area might have different sedimentation processes than the center of the study area. This condition may stretch to the west and made the western part of the study area has a lower soft-sediment deposit.

The area with more sediment deposit has a higher risk when an earthquake happens. The earthquake wave would be amplified or prolonged. The damage to the building in the area with a thick sediment deposit would be worse. Therefore, the reactor building would be better if located in the area with lower sediment thickness. This condition also related to engineering planning in the construction process. If the reactor is located in the area that has a high sediment deposit, the engineering would cost higher to anticipate higher wave amplification and ground acceleration.

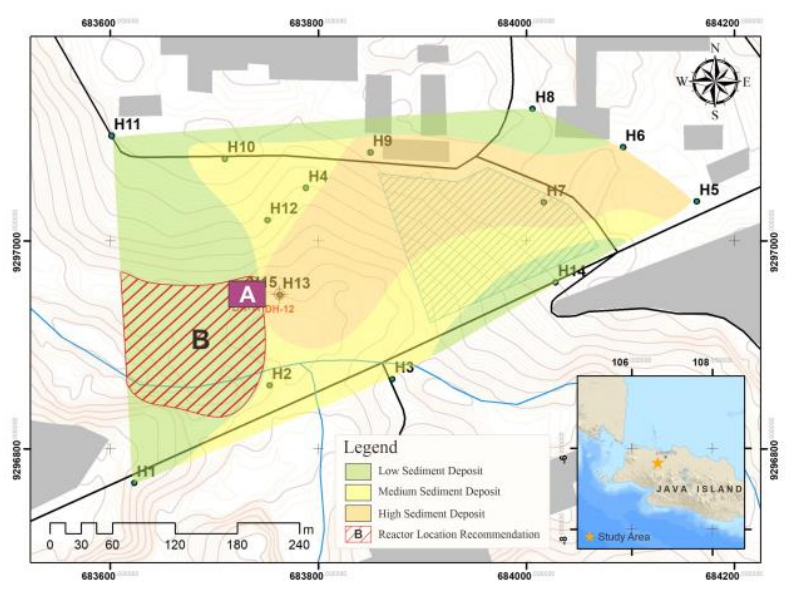

Figure 8. The Area Classification Based on Sediment Deposit.

Figure 8 shows the simplified map and the classification of the sediment thickness based on the calculation result. The sediment thickness in this area was classified into three levels: the high sediment deposit shown with the orange colored area; the medium sediment deposit with the yellow colored area; and the low sediment deposit with the green colored area. The location of the reactor is recommended to be in the green zone. The current selected reactor position (A) was already in the green zone. However, this location is presumed too close to the high sediment deposit area. Based on the sediment thickness factor, the reactor would be safer if it is built to the west of the current location in the green zone area.

This study has limitations, especially in limited data. Regardless of this limitation, the $\mathrm{B}$ area, which is around $60 \mathrm{~m}$ from A, is proposed for the reactor building location. This area is predicted to have a lower sediment deposit 
based on the data interpolation result. The proposed area also has a flat topography that could lower the cost of the engineering.

\section{CONCLUSION}

Based on the results, the area around 60 $\mathrm{m}$ west of the currently proposed reactor is suggested for an alternative location. The current proposed reactor location already has a relatively low sediment deposit with $8,8 \mathrm{~m}$ of thickness. Still, the alternative location and its surroundings have a lower sediment deposit with up to $7 \mathrm{~m}$ of thickness. Therefore, this area has better seismic hazard safety.

\section{ACKNOWLEDGEMENT}

This study was financed by the Center for Nuclear Energy System BATAN. The author expresses gratitude to Dr Suparman as the Head of Center for Nuclear Energy System BATAN and Dr Sunarko as the Head of Site Assessment Division for their supports and contributions on this study.

\section{REFERENCES}

[1] Presidential Decree No. 2, Rencana Pembangunan Jangka Menengah Nasional Tahun 2015-2019. Indonesia, 2015.

[2] J. A. Katili, "Geochronology of West Indonesia and Its Implication on Plate Tectonics," Tectonophysics, vol. 19, pp. 195-212, 1973.

[3] IAEA, Seismic Hazards in Site Evaluation for Nuclear Installations SSG-9, vol. 8. 2010, p. 80.

[4] Badan Pengawas Tenaga Nuklir (BAPETEN), Evaluasi Tapak Instalasi Nuklir Untuk Aspek Kegempaan. Indonesia, 2013

[5] J. Gomberg, "Cascadia Onshore-Offshore Site Response, Submarine Sediment Mobilization, and Earthquake Recurrence," J. Geophys. Res. Solid Earth, vol. 123, no. 2, pp. 1381-1404, 2018, doi: 10.1002/2017JB014985.

[6] R. M. Ceballo et al., "Effects of Sediment Thickness upon Seismic Amplification in the Urban Area of Chiapa de Corzo , Chiapas , Mexico," Earth Sci. Res. J., vol. 23, no. 2, pp. 111-117, 2019.

[7] L. G. Hinzen, B. Weber, and F. Scherbaum, "On The Resolution of $\mathrm{H} / \mathrm{V}$ Measurements to Determine Sediment Thickness, A Case Study Across A Normal Fault in The Lower Rhine Embayment, Germany," J. Earthq. Eng., vol. 8, no. 6, pp. 909926, 2004, doi: 10.1080/13632460409350514.

[8] V. D. Amico, M. Picozzi, and D. Albarello, "Quick
Estimates Of Soft Sediment Thicknesses From Ambient Noise Horizontal To Vertical Spectral Ratios: A Case Study In Southern Italy," J. Earthq. Eng., vol. 8, no. 6, pp. 895-908, 2004.

[9] D. Liang, F. Gan, W. Zhang, and L. Jia, "The Application of HVSR Method in Detecting Sediment Thickness in Karst Collapse Area of Pearl River Delta, China," Environ. Earth Sci., vol. 77, no. 6, pp. 1-9, 2018, doi: 10.1007/s12665-018-7439-x.

[10] R. Biswas, S. Baruah, and D. K. Bora, "Mapping Sediment Thickness in Shillong City of Northeast India Through Empirical Relationship," J. Earthquakes, vol. 2015, pp. 1-8, 2015, doi: $10.1155 / 2015 / 572619$

[11] P. Bard, "Microtremor Measurement: A Tool for Site Effect Estimation?," Eff. Surf. Geol. Seism. Motion, K. Irikura K. Kudo H. Okada T. Sasatami Eds, no. August, pp. 1251-1279, 1998.

[12] Y. Nakamura, "Method for Dynamic Characteristics Estimation of Subsurface Using Microtremor on the Ground Surface," Q. Rep. RTRI (railw. Tech. Res. Institute), vol. 30, no. 1, pp. 25-33, 1989.

[13] H. Yamanaka, M. Takemura, H. Ishida, and M. Niwa, "Characteristics of Long-Period Microtremors and Their Applicability in Exploration of Deep Sedimentary Layers," Bull. Seismol. Soc. Am., vol. 84, no. 6, pp. 1831-1841, 1994, doi: 10.1016/0148-9062(95)99176-x.

[14] M. I. Von Seht and J. Wohlenberg, "Microtremor Measurements Used to Map Thickness of Soft Sediments," Bull. Seismol. Soc. Am., vol. 89, no. 1, pp. 250-259, 1999.

[15] S. Parolai, P. Bormann, and C. Milkereit, "New Relationships Between Vs, Thickness of Sediments, and Resonance Frequency Calculated by the H/V Ratio of Seismic Noise for the Cologne Area (Germany)," Bull. Seismol. Soc. Am., vol. 92, no. 6, pp. 2521-2527, 2002, doi: $10.1785 / 0120010248$.

[16] E. R. Iswanto, Y. Indrawati, and T. A. Riyanto, "Studi Mikrotremor dengan Metode Horizontal to Vertical Spectral Ratio ( HVSR ) di Tapak RDE , Serpong Microtremor Study using Horizontal to Vertical Spectral Ratio ( HVSR ) Method in RDE Site , Serpong," Eksplorium, vol. 40, no. 2, pp. 105114, 2019, doi: 10.17146/eksplorium.2019.40.2.5489.

[17] M. Wathelet et al., "Geopsy: A User-Friendly Open-Source Tool Set for Ambient Vibration Processing," Seismol. Res. Lett., vol. 91, no. 3, pp. 1878-1889, 2020, doi: 10.1785/0220190360.

[18] M. K. Koçkar and H. Akgün, "Evaluation of The Site Effects of The Ankara Basin, Turkey," J. Appl. Geophys., vol. 83, no. January 2019, pp. 120-134, 2012, doi: 10.1016/j.jappgeo.2012.05.007.

[19] BATAN, "Laporan Evaluasi Tapak Aspek Geoteknik dan Pondasi," Jakarta, 2016.

[20] W. B. Joyner and D. M. Boore, "Measurement, Characterization, and Prediction of Strong Ground Motion," in Earthquake Engineering and Soil Dynamics II, Proceedings of American Society of Civil Engineers Geotechnical Engineering Division Specialty Conference, 1988, pp. 43-122, doi: 10.1017/CBO9781107415324.004.

[21] V. Poggi, B. Edwards, and D. Fäh, "The QuarterWavelength Average Velocity: A Review of Some Past and Recent Application Developments," in In 
Proceedings of the 15th World Conference on Earthquake Engineering, 2012, vol. No. 4242.

[22] M. S. Fnais, K. Abdelrahman, and A. M. Al-Amri, "Microtremor Measurements in Yanbu City of Western Saudi Arabia: A Tool for Seismic Microzonation," J. King Saud Univ. - Sci., vol. 22, no. 2, pp. 97-110, 2010, doi: 10.1016/j.jksus.2010.02.006.

[23] H. Livaoğlu and T. S. Irmak, "An Empirical Relationship Between Seismic Bedrock Depth and Fundamental Frequency for DEğIrmendere (Kocaeli-Turkey)," Environ. Earth Sci., vol. 76, no. 20, 2017, doi: 10.1007/s12665-017-7025-7.

[24] Building Seismic Safety Council (FEMA 450), "Nehrp Recommended Provisions for Seismic Regulations for New Buildings and Other Structures (Fema 450)," Part 1, no. Fema 450, p. 338, 2003, doi: 10.1016/j.compgeo.2013.09.005.

[25] W. C. Teng, Foundation Design, 13th editi. Englewood Cliffs, N.J., USA: Prentice-Hall, Inc., 1962.

[26] P. G. E. F. Augustinus and S. Slager, "Soil Formation in Swamp Soils of the Coastal Fringe of Suriname," Geoderma, vol. 6, no. 3, pp. 203-211, 1971, doi: 10.1016/0016-7061(71)90063-2. 